\title{
Pragmatic Force of Covid-19 Ads as Health Protection Practices in Mass Media Discourse: A Contrastive Analysis Study
}

\author{
Merve GEÇIKLL ${ }^{1}$
}

\begin{abstract}
Moving on speech act theory, this study aims to analyse texts in Covid-19 Ads from different parts of the world in order to explore the pragmatic force of mass media discourse across contexts. Thus, the data source of the study is 450 Covid-19 Ads from countries in Asian context, in European context, and in American context compiled from the websites of countries national web platforms. Following qualitative paradigm, the linguistic functions of Covid19 Ads were analysed on the basis of descriptive analysis moving on ready-made categories in order to compare and contrast the sort of pragmatic force employed in Ads. The overall findings show that, regarding the frequency of illocutionary acts across contexts, there are no significant differences among the Ads in terms of the pragmatic force. Directives and assertives were found to be the most frequent illocutionary acts in texts. In this respect, Covid-19 Ads seemingly perform the same function in mass media discourse of Asian, European, and American contexts; that is, the public discourse is pragmatically manipulated by the Ads for the sake of health protection practices.
\end{abstract}

Key Words: Pragmatic Force, Speech Act Theory, Covid-19 Ads, Mass Media Discourse, Contrastive Analysis, Pragmatics

\section{Medya Söyleminde Sağlık Koruma Faaliyeti Olarak Covid-19 Reklamlarının Edimsel Eylemi: Bir Karşıtsal Çözümleme Çalışması}

\section{$\ddot{O} z$}

Söz eylemi teorisini temel alan bu çalışma; dünyanın farklı yerlerinde yayınlanmış Covid-19 odaklı reklamlardaki metinlerin, farklı ortamlardaki medya söyleminin edimsel eylemini keşfetmek üzere analizini amaçlamaktadır. Bu bağlamda, çalışmanın veri kaynağını Asya, Avrupa ve Amerika'da çeşitli ülkelerin web plaformlarında yayınlanmış 450 adet reklam oluşturmaktadır. Nitel paradigmadan hareketle, Covid-19 reklamlarındaki dil işlevleri, reklamlardaki edimsel eylemin karşıtsal çözümleme ile irdelenmesi için, hazır kategorilere dayanan betimsel analiz ile analizi yapılmıştır. Çalışmanın genel bulguları, bağlamlar arasında eimsel eylemlerin kullanım sıklıklarında pragmatik güç açısından reklamlarda bir farklılık olmadığını göstermektedir. Bu bakımdan, Covid-19 reklamları, Asya, Avrupa ve Amerika'daki bağlamlardaki medya söylemi içerisinde aynı işlevi yerine getirmektedir ve bu işlevinde şu şekilde olduğu çıkarımına varılabilir; reklamlar kamu söylemini, sağlık koruma eylemleri gereği, pragmatik olarak yönlendirme eğilimindedir.

Anabtar Kelimeler: Pragmatik Güç, Söz Eylem Teorisi, Kovid-19 Reklamları, Medya Söylemi, Karşıtsal Çzöümleme, Edim Bilim

\section{Atıf İçin / Please Cite As:}

Geçikli, M. (2021). Pragmatic force of Covid-19 ads as health protection practices in mass media discourse: A contrastive analysis study. Manas Sosyal Arasttrmalar Dergisi, 10(2), 1214-1224.

Geliş Tarihi / Received Date: 30.03.2021

Kabul Tarihi / Accepted Date: 12.04.2021

\footnotetext{
1 Assist. Prof. Dr. - Atatürk University, Kazım Karabekir Faculty of Education, merve.gecikli@atauni.edu.tr, 


\section{Introduction}

The communication tools/genres including channels, and modes have been re-shaped or new ones have been introduced with the ongoing reciprocal relationship between digitalization, digitization, and globalisation (Zembylas \& Vrasidas, 2007); these tools/genres, with their elaborate and multi-dimensional structure, of the mass media discourse have dramatically played role in shaping public behaviours and attitudes towards events and issues through not only visually abut also linguistically sophisticated content that could manage and re-change the already-constructed discourse of public (e.g. Bernhardt, Krasa, \& Polborn, 2008; Bertrand, Karlan, Mullainathan, Shafir, \& Zinman, 2010; Chiang \& Knight, 2011; DellaVigna \& La Ferrara, 2016; Gambaro \& Puglisi, 2015; Gerber, Karlan, \& Bergan, 2009; Kearney \& Levine, 2015). In this regard, with the break of COVID-19 pandemic, one of the global positions mass media discourse seems to seriously take, driven from health protection manipulation of governments, has been to inform and educate publics about COVID-19 pandemic facts with oriented messages that would be expected to have impact upon publics' understanding of the issue and, accordingly, adapting to 'the new normal'. However, as COVID-19 pandemic is a rather new raising issue, there is little data on the role of mass media discourse in information and attitude management and how the content of the messages shared in the mass media tools are structured (e.g. Gonzalez-Padilla \& Tortolero-Blanco, 2020; Smith, Smith, \& Ajayi, 2020; Tasnim, Hossain, \& Mazumder, 2020). Furthermore, the linguistic communicative aspects of the texts regarding COVID-19 pandemic embedded in mass media tools have never been obviously issued within the scope of pragmatics, a focus on which would indeed expand knowledge on the linguistic characteristics of texts by providing evidence for how discourses are working in persuading their target community. Thus, this research paper aims to analyse the functions of texts in a mass media tool/genre, advertisements (from now on, Ads), on the basis of speech act theory (Austin, 1962; Searle, $1969,1979)$ in order to explore the pragmatic force of mass media discourse semantically by comparing samples from different contexts of the world. In the following sections, relying on relevant literature, firstly, the mass media discourse will be issued with an emphasis on its character as awareness booster especially with reference to health protection practices. Then, the theoretical framework of speech act theory will be briefly established by explaining what sort of actions texts as utterances may perform. Later, the methodology of the current study will be mentioned through further information about the research design followed and data collection and analysis procedures. The paper will conclude with findings, discussion, and conclusion parts.

\section{Mass Media Discourse as Health Awareness Booster and Health Protection Mediator}

Mass media discourse, through the tools, techniques, and procedures such as campaigns, Ads, ..etc., is one of the mediator as awareness booster commonly and intentionally intervened in health protection services. In fact, media discourse has been used in changing health perception by addressing issues about diagnosis, treatment, and prevention. At this point, the messages integrated about COVID-19 influenza within mass media discourse since the outbreak have seemingly been focused ones about re-regulation of social life by raising awareness about, specifically, self-diagnosis and prevention with an aim to affect health behaviours of public (e.g. González-Padilla \& Tortolero-Blanco, 2020; Mejia et al., 2020; Sharma, Gupta, Kushwaha, \& Shekhawat, 2020; Smith et al., 2020). In this regard, the Covid-19 Ads structured and composed by agencies through the intervention of states have seemingly placed Covid-19 stories in mass media as a publicity and public relation practice (Adegoke, 2001) in order to bring facts to public notice and to sway public in responding in a way targeted in the Ads.

In the literature, studies commonly emphasize that the discourse managed in mass media about the epidemics and pandemics in the past have played a crucial role in controlling the infection through public health education campaigns as awareness boosters (Cui, Sun, \& Zhu, 2008; Jung, Lin, \& Viswanath, 2013; Lau, Yang, Tsui, \& Kim, 2003; Majumder, Kluberg, Santillana, Mekaru, \& Brownstein, 2015; Wang, Zhao, Huang, Yang, \& Wu, 2015). Generally, researchers outline how the persuading strategies in mass media campaigns can contribute to the decrease in contamination through determined messages on such as hand washing or social distancing (Roth \& Henry, 2011). As for the overall remarks of these studies, it is reported that information dissemination through mass media tools for public health protection is critical in shaping behaviours by resulting in change of public daily actions, and so the use of the genres and strategies in mass media discourse is suggested (Catalan-Matamoros, 2011; Hornik, 2002; Majumder et al., 2015). The same effect was also observed during Covid-19 pandemic; in the studies by Lunn et al. (2020) and Al-Dmour, Masa'deh, Salman, Abuhashesh, and Al-Dmour (2020), it was found that media coverage 
of points regarding Covid-19 pandemic significantly increased " public health protection and public health awareness"(pp. 9-10-11). On this basis, authors pointed out that mass media discourse can be effectively managed by governments and decision makers in enhancing public awareness on Covid-19 and relevant precautions public would take through dissemination of knowledge.

Overall, the studies seemingly confirm the potential of mass media discourse in raising public awareness and increasing public health protection in controlling the infection of epidemics and pandemics through scoping relevant social dimensions of phenomena with techniques and tools integrating advertising, publicity, and public relations practices (Al-Surimi, Khalifa, Bahkali, Ashraf, \& M., 2017; Pagoto, Waring, \& Xu, 2019). Moving on these confirmed conclusions, the current study is motivated to dig data about the rhetoric in one of the mass media genres, Ads in order to explore the linguistic aspects of mass media discourse and thus to shed light on the role of rhetoric importance in persuading the target community, amid Covid-19 pandemic, public. In this regard, considering the pragmatic side of Ads in terms of linguistic dimensions operated in the texts, it is believed that it would be of significance to compare the Ads in different contexts by following the logic put by Austin $(1962)$ and Searle $(1969,1979)$ within the scope of their Speech Act Theory.

\section{Speech Act Theory}

Speech Act Theory was introduced by Austin (1962, pp. 9-10-11) and developed by Searle (1969, 1979) on the basis of their analysis about how lexemes can perform some certain acts in written and spoken texts or utterances. Specifically, Austin (1962) emphasizes that any utterance produced performs locutionary, illocutionary, and perlocutionary acts. At this point, locutionary act is defined as the literal or propositional meaning of a linguistic expression, that is, the basic or original sense of a word, denotation (Autores et al., 2010). Illocutionary act, also called as speech act or illocutionary force, refers to the intention or the meaning intended by the producer of the text. At this point, the intended meanings of the locution uttered could be categorized as assertive acts (e.g., statements), commissive acts (e.g., promises), directive acts (e.g., commands), expressive acts (e.g., avowals of emotion), and declarative acts (e.g., christenings) (Searle, 1969, 1979). At this point, the nature of illocutionary force is socially situated; that is, the meaning intended, to certain extent, depends on the conditions of immediate context. Also, semantically, the intended meaning of some locutions should be the propositional or literal meaning of these utterances because of the situations beyond the interlocutors. For example, it would be impossible for an interlocutor to guarantee the change of a course of actions already officially scheduled; therefore, the lexeme of ' to guarantee' requires to be literally meant. Then, context, where individual, institutional, physical, historical, spatial, and temporal aspects would matter, seems to affect the illocutionary force of the linguistics expression. The final act to be performed or probably to be performed through the locution is perlocutionary act, which betokens the change expected to be seen in the act of the addressee as a consequence of linguistic expression. Then, some acts interlocutors perform can be perlocutionary when one of the interlocutors could manage to make the other party in interaction do the thing s/he means to. For example, requesting is a perlocutionary act where parties in conversations are asking for a task, an action, or a function to fulfil.

In this regard, the current study basicly moves on the illocutionary force of linguistic expressions in COVID-19 Ads, rather than the perlocutionary act because, although the nature of expressions could also cover a perlocutionary force with an expected result, to measure the perlocutionary force, there would need to use other measures such as scales to explore any attitude change in addressees, which is beyond the scope of this study. Thus, the pragmatic force in mass media discourse during COVID-19 pandemic was focused through the relevant Ads by specifically analysing texts by looking for the semantic modification of the lexemes as illocutionary forces.

\section{Methodology}

\section{Research Design}

In the analysis of the texts produced within contexts, how the language is patterned in shaping and reflecting on understandings on events, points, notions, and phenomena is generally the main concern of discourse analysis paradigm (Fairclough, 1995a; Jorgensen \& Philips, 2002). In mass media discourse, discourse analysis studies are commonly based on critical discourse analysis perspective, which specifically addresses the study on the social change betokened in the linguistic pieces (Fairclough, 1992, 1995a, 1995b). Accordingly, the current study took this stance fixed within discourse and critical discourse 
analysis paradigms by considering that, through this stance, the rhetoric in Covid-19 ads would be thoroughly studied. At this point, as it is a text and context-based research, the design of the study is much more qualitatively oriented because, to qualitative perspective, reality is multiple, context, and valuebound (Maykut \& Morehouse, 1994). Thus, the main aim of this study is to compare and contrast the texts in Covid-19 Ads across different contexts of mass media discourse in order to explore pragmatic force, in other words illocutionary force, in texts functioning as health protection practices.

\section{Data Source, Data Collection and Analysis Procedures}

The data of the study were 450 Covid-19 Ads from countries in Asian contexts, in European contexts, and in contexts of American continent purposefully selected from the websites of countries national web platforms. In this regard, as this a cross-cultural study based on contrastive rhetoric, there raises the issue of comparable corpora, which requires to be addressed carefully. At this point, the researcher followed the dimensions outlined by Moreno (2008, pp. 5-6) discussing that the main point in contrastive rhetoric studies is to deal with the communicative functions of the texts in terms of the conviction and commitment displayed. Thus, the Ads were compiled on the basis of "building parallel corpora" (p. 5) and "identifying equivalent textual concepts" (pp. 5-6) to be studied. Accordingly, by considering from socio-cultural and cognitive perspective, the first criterion was to determine the channel to be focused; as pointed out in the literature, in pandemics and epidemics mass media discourse is of value in public health protection and raising awareness, so as one of the channel in directly reaching target community, namely public, Ads are commonly emphasized in the literature on the role of shaping behaviours (Chan, 2000; Cho, Oehlkers, Mandelbaum, Edlund, \& Zurek, 2004; Kim, 2006) and, hence, Ads, specifically Covid 19 Ads, were selected as the channel to be analysed in the study.

Figure 1. Illocutionary acts in Speech Act Theory by Austin (1962) and Searle (1969, 1979)

\begin{tabular}{|c|c|c|}
\hline ILLOCUTIONARY ACTS & DESCRIPTION & ENGLISH VERBS \\
\hline \multirow{2}{*}{ ASSERTIVES } & ASSERTIONS, CLAIMS, REPORTS & \multirow{2}{*}{$\begin{array}{l}\text { assert, claim, affirm, assure, inform, } \\
\text { predict, report, suggest, insist, } \\
\text { hypothesize, swear, admit, confess, } \\
\text { blame, praise }\end{array}$} \\
\hline & Can be verified as true or false & \\
\hline \multirow[t]{2}{*}{ DIRECTIVES } & $\begin{array}{l}\text { SUGGESTIONS, REQUESTS, } \\
\text { COMMANDS }\end{array}$ & \multirow{2}{*}{$\begin{array}{l}\text { direct, request, ask, urge, demand, } \\
\text { command, forbid, suggest, insist, } \\
\text { recommend, implore, beg }\end{array}$} \\
\hline & Call upon listener to do something & \\
\hline \multirow{2}{*}{ COMMISSIVES } & PROMISES, OFFERS & \multirow{2}{*}{$\begin{array}{l}\text { Promise, vow, fledge, swear, consent, } \\
\text { refuse, assure, guarantee, contract, bet }\end{array}$} \\
\hline & Commit to a course of action & \\
\hline \multirow{2}{*}{ EXPRESSIVES } & $\begin{array}{l}\text { APOLOGIES, COMPLAINT, } \\
\text { THANKS }\end{array}$ & \multirow{2}{*}{$\begin{array}{l}\text { Apologize, thank, condole, } \\
\text { congratulate, complain, protest, } \\
\text { compliment, praise, welcome }\end{array}$} \\
\hline & $\begin{array}{l}\text { Express a psychological position about a } \\
\text { state of affairs }\end{array}$ & \\
\hline \multirow[b]{2}{*}{ DECLARATIVES } & DECREES, DECLARATIONS & \multirow{2}{*}{$\begin{array}{l}\text { fire, pronounce, declare, appoint, } \\
\text { confirm, endorse, renounce, denounce, } \\
\text { name, call, repudiate }\end{array}$} \\
\hline & $\begin{array}{l}\text { Change the reality in accord with the } \\
\text { proposition of the declaration }\end{array}$ & \\
\hline
\end{tabular}

Followingly, the researcher decided which contexts would be the focus of the current study; here, the contexts were fixed by considering that they will be the "representative of the population" (Moreno, 2008, p. 6), which means text configuration to large extent depends on the variation across contexts. As a result, by consulting with the academics in advertising departments at two universities in Turkey, the contexts decided were Asian context, European context, and American context, which the academics discussed would represent not only context-specific assumptions but also universal aspects; in other words, there are both similarities and differences across contexts. As for the language code, only the English Covid-19 Ads in the contexts could be selected as English is the second language of the researcher and the other two raters of the study, which is one of the limitation of the current study because, in contrastive rhetoric studies, it is generally suggested to compare the corpora in two different languages (Connor \& Moreno, 2005). Still, there are also studies in the literature comparing English texts of non-native speakers in order to see the rhetoric performance of communities from different linguistic backgrounds in second or foreign language; this kind of studies provided further details about the similarities and differences across contexts in discursive practices in texts.

As data collection tool, the researcher preferred to follow the illocutionary acts identified within the Speech Act Theory, shown in the figure below. In this regard, due to this scope, this theory enables a 
thematic framework to analyse texts in categorical pieces. Specifically, in each category there are certain illocutionary acts typified used by text producers in order to announce specific intentions to the aim of a change in the practices of target community; then, regarding the role of mass media discourse, and specifically Ads, in the change of large mass' actions, it would be meaningful to analyse the texts in Covid19 Ads on the basis of this thematic structure Speech Act Theory provides (see Figure 1).

As for data collection, before starting coding, the researcher of the study directed the other two coders, from the department of advertising in a public university in Turkey, about how Ads would be coded on the basis of Speech Act Theory; besides, the researcher consulted the coders about the scientific dimensions of Ads. Followingly, the researcher and these two coders started to code the Ads; in this process, as well as independent coding, at some points, we met once a week for a general consensus. Then, through percentage agreement, inter-coder reliability was checked (O'Connor \& Joffe, 2020), and the overall agreement across coders was $73.51 \%$.

For the analysis of corpora, the occurrence frequency and percentage distribution of each category were calculated through data entry into IBM SPSS 20. Also, as the main aim of the study is to compare Covid-19 Ads, the differences among the corpora were also measured through chi-square analysis and used $\mathrm{P}$ values showing the statistical significance of difference (the value less than .001), but, as there was found no significant difference across corpora, the researcher decided not to use these statistics.

\section{Findings and Discussion}

The distribution of illocutionary acts across contexts are presented in Graphic 1, Graphic 2, and Graphic 3, respectively. In this regard, specifically, the first graphic is a tree map, which displays the hierarchical data of Covid-19 Ads by illocutionary acts; here, the rationale behind the use of treestructured data visualization is to show, through the size and colour of nested rectangles, the scalability showing the proportion of illocutionary acts in whole discourse. As for second graphic, star plot diagram, it was used to represent the length of illocutionary act spokes to the context points. Thus, the magnitude of each illocutionary act across Ads in European, Asian, and American contexts is presented. The matrix in Graphic 3 outlines categorically the occurrence of directives, assertives, commissives, declaratives, and expressives in the Covid-19 Ads of each context.

As it is seen in Graphic 1, hierarchically, the most frequent illocutionary acts performed in the Covid19 Ads are directives and assertives, respectively. Proportionally, in \% 28 of the Covid-19 Ads, directives are performed while assertives were found in $\% 27$ of the corpus. As for other illocutionary acts, the expressives are the least frequently used ones in the Covid-19 Ads (\%6). On the other hand, approximately \% 20 of the corpus involves commissives while declaratives are covered in \%19 of the Ads. In this respect, the Covid-19 Ads were probably designed to the aim of managing the public discourse in order to trigger a change in the individual behaviours.

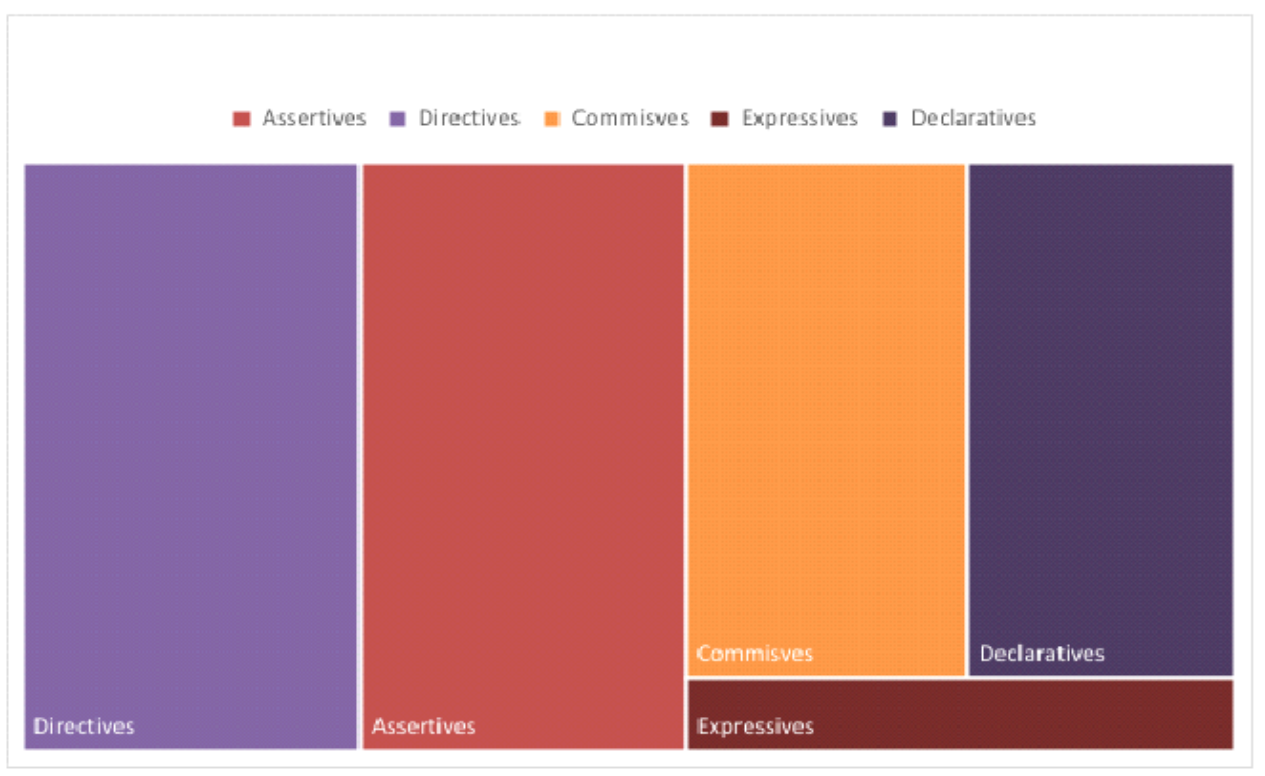

Graphic 1. Hierarchical Distribution of Illocutionary Acts in the Whole of Covid-19 Ads 
Functionally, the main motive behind the Ads is seemingly to call upon the public to re-organize their daily actions on the basis of pandemic facts reported and affirmed through assuring risk management and listing the recommendations directly and indirectly. Here, it is essential to point out that, in management of public discourse, the Ads were also apparently organized with an intent to emphasize the reality changed by Covid-19 pandemic declaration. Moreover, the texts in Covid-19 Ads obviously addresses to an ad hoc agreement for public to consent to a course of actions they will adopt and to take responsibility as health protection practices. The following sample extracts from the Covid-19 Ads seemingly prove this:

Extract 1. (Asian context): "It is time to stay at home for us/him/her/them" (https://www.adsoftheworld.com/media/film/united_nations_covid19_we_are_at_home_to_protect_yo u)

Extract 2. (European context): "Let's keep to do all we can to protect each other and stop spread" (https://tr.adforum.com/creative-work/ad/player/34630922/stop-the-spread/nhs)

Extract 3. (American context): "Nurses do for $12 \mathrm{hr}$. You can for 12 min. Wear the mask." (https://creativeenergy.agency/portfolio/mask-campaign/)

Extract 4. (American context): "Back to normal is up to you. Wear a mask" (https://www.thedrum.com/creative-works/project/mccann-worldgroup-mucinex-back-normal-up-you )

Extract 5. (European context): “ Keep the distance. Stay safe” (https://laptrinhx.com/jazas-keep-thedistance-2189234213/)

Extract 6. (European context): "Giving up the handshake can save lives. Goodbye to the handshake" (https://www.youtube.com/watch?v=iilVm-DU_D0\&t=3s)

Extract 7. (Asian context): "It is your choice..." (https://www.bestadsontv.com/ad/117632/KonyaMetropolitan-Municipality-Its-Your-Choice-2)

On this basis, these text-based findings suggest that, as stated in the previous research on the role of mass media in discourse management during epidemics and pandemics (Cui et al., 2008; Jung et al., 2013; Lau et al., 2003; Majumder et al., 2015; Wang et al., 2015), amid Covid-19, the Ads about pandemic in mass media discourse have made effort to re-shape the daily life of individuals through organizing the texts in a way that will manage the perception of public regarding the organization of life routines. Accordingly, it is possible to conclude that Ads about Covid-19 and relevant points seem to boost the awareness about the social acts the public could put on and precautions it may take against the spread of Covid-19. In fact, the higher frequency of directives and assertives obviously proposes how the content of Ads, as one of perception management tool of mass media discourse, were intentionally designed to be part of health protection services; given the findings of the studies in the literature pointing out the effect of mass media during Covid-19 pandemic (Al-Dmour et al., 2020; Lunn et al., 2020), it was understood that the text material in Ads were organized and determined to have impressive effect in mediating health protection practices.

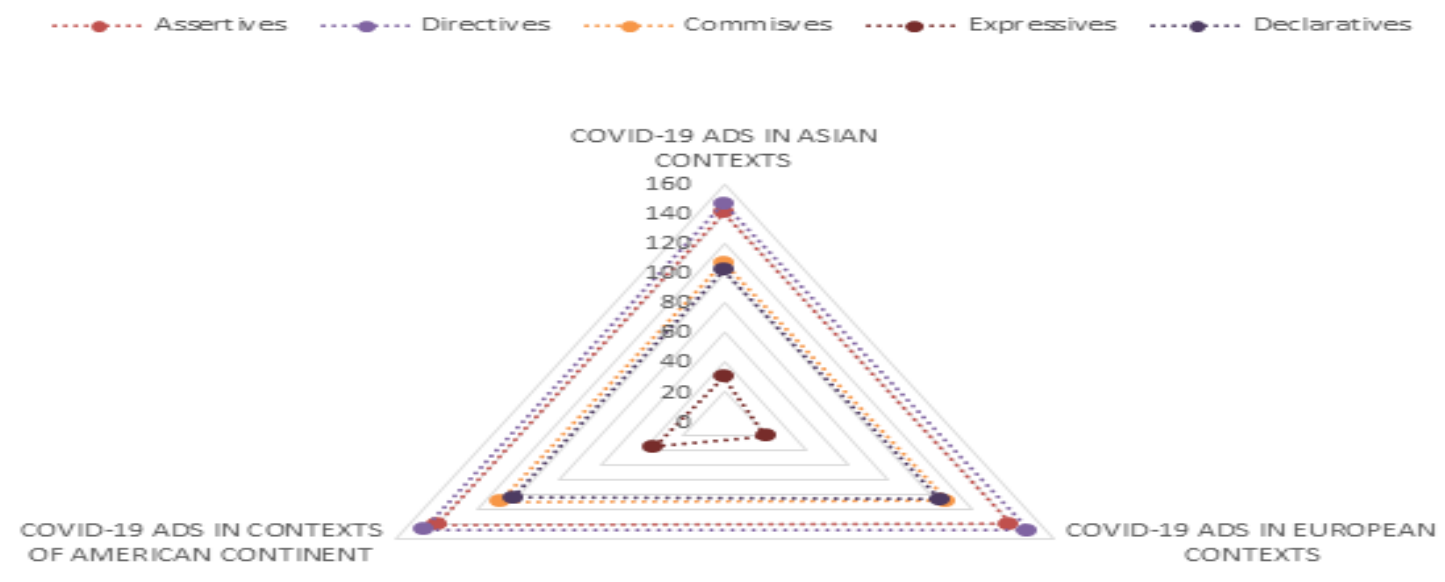

Graphic 2. Star Plot of Illocutionary Acts and Covid-19 Ads in Contexts 


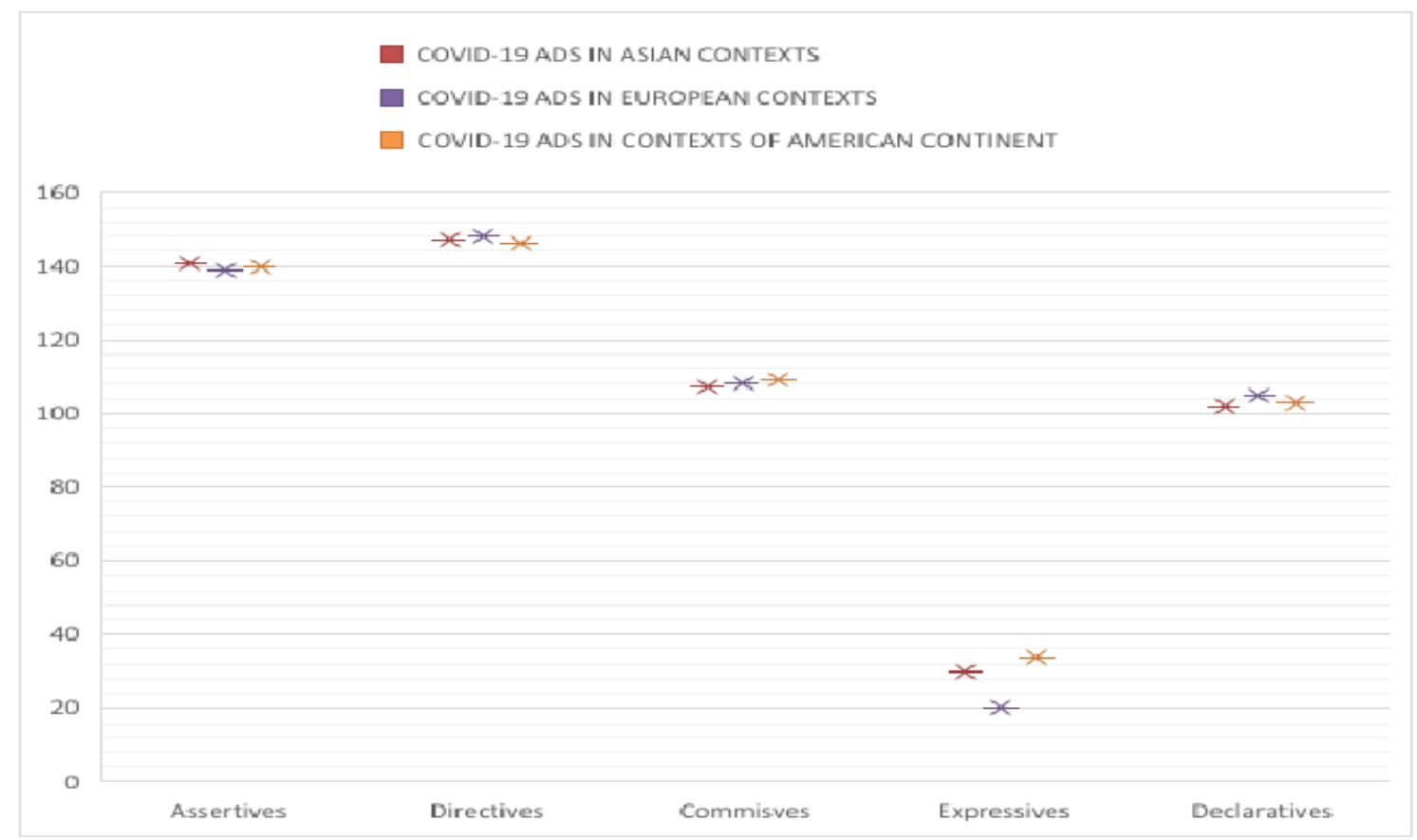

Graphic 3. Matrix of Illocutionary Acts across Covid-19 Ads in Asian Contexts, in European Contexts, and Contexts in American Continent

As to Graphic 2 and Graphic 3, despite from different contexts, with respect to the occurrence of illocutionary act types, the findings show striking commonality among Ads. Directives and assertives are the most frequent acts performed in the Ads of each context, respectively.; specifically, in European, American, and Asian contexts, above 35 percent of Ads cover directives while assertives were rated in the approximately 30 percent in the Covid-Ads of each context. As for other acts, the Ads in each context are composed of about 20 percent commissive and declaratives while the expressives are the least frequent ones. In this regard, it is essential to point out that expressives is the category in which there is observed a difference across the contexts. That is, in Covid-19 Ads of Asian contexts, the percentage of expressive acts is $6 \%$ while it is 3\% in the Ads of American contexts, and following, $1 \%$ in those of European contexts. Actually, the frequently emphasized role of mass media tools in information dissemination for public health protection during epidemics and pandemics in the literature (Catalan-Matamoros, 2011; Hornik, 2002; Majumder et al., 2015) may explain this quite less occurence of expressives in the Covid-19 Ads because the function of expressive acts are to convey a psychological position about a situation or set of circumstances rather than informing, recommending, assuring, or declarating. Still, compared to the Ads in European and American contexts, expressive acts were observed more frequently in the Coivd-19 Ads of Asian mass media contexts, which may be due to cross-cultural differences in emotion (Lim, 2016). Nevertheless, the commonality across the Ads of mass media discourses from Asian, European, and American contexts indicates that the driving force of Covid-19 pandemic as a global raising issue, in all likelihood, caused mass media discourse to structure the content of the texts in Ads in a way that would sharpen public perception on the dimensions of Covid-19 pandemic and increase their ability to adapt to the new normal to the latest formalities of daily life. Thus, it appears that mass media discourses in different parts of the world follow similar discursive strategies in the texts about Covid-19 and pertinent essences.

\section{Conclusion, Limitations, and Suggestions}

In the litertaure, there are studies about the effect of mass media discourse on raising public awareness as public health protection services in order to control the infection of epidemics and pandemics (Al-Surimi, Khalifa, Bahkali, Ashraf, \& M., 2017; Pagoto, Waring, \& Xu, 2019) including Covid-19 pandemic (Al-Dmour et al., 2020; Lunn et al., 2020). Still, there is no any specific study focusing on the textual content of the tools/genres used in mass media discourse. Driven from this gap, the current study aimed at analysing the texts in one of mass media tools, Ads, in different parts of Asian, American, and European contexts by following both discourse and critical discourse analysis paradigms and on the basis of contrastive analysis framework. Hence, this study have outlined why texts in mass media tools 
should be focused in understanding the discursive mentality maintained during epidemic and pandemic, for now, specifically Covid-19 pandemic. In this respect, the logic put by Austin (1962) and Searle (1969, 1979) in Speech Act theory was pursued because, thanks to the categories and details in each category, this theory creates a space for analysis on pragmatic aspects of scripts in mass media discourse. Specifically, the researcher built the research on the illocutionary acts performed in the Covid-19 Ads in order to explore the pragmatic force of Ads amid Covid-19 pandemic. Here, it is significant to highlight that, as this study just centred around texts, only illocutionary acts could be studied rather than perlocutionary acts, which requires observing and noting public social acts. As to the overall findings of the study, there is commonality observed across the Covid-19 Ads in mass media discourses of Asian, European, and American redgarding the sort of illocutionary acts operated. Particularly, directives and asertives are the most frequent acts performed in the texts while the expressives occured quite less in the Ads. On this basis, overally, it seems that, though the Covid-19 Ads were constructed in non-identical mass media discourses in the world, the mass media discourses performed the same the pragmatic force in the texts of Ads; the aim was to enlighten the public about Covid-19 pandemic and to persuade them to re-arrange their social acts and thus to ease adaptation to new normal. In this aspect, it is possible to indicate that Covid-19 Ads in Asian, European, and American contexts worked as health awareness boosters and health protection mediators, and so they made effort to contribute to the health protection services of governments.

Although this study adressed a gap in the literature by focusing on the textual based points in order to explore the discursive practices in mass media across several contexts, it is not the limited one. First of all, as this study is a text-based research, the probable effect of the Covid-19 Ads on public in terms of attitude change was not focused. At this point, further studies may adress this gap by collecting not only textual but also numerical data through following both qualitative and quantitative paradigms synchronically through different data collection tools such as surveys, observations, interviewing, documents, which will then deepen understaing about the sort of discourse managed and the public discourse. Besides, in this study just the Ads in Asian, American, and Eurpean contexts and specifically the ones in English were focused; thus, researchers can repeat the same study by expanding the scope with a cover of the other parts of the world and other genres as well as the Ads in local languages in order to explore whether there are cultural differences regarding the sort of discourse operated in mass media of local areas. Also, in this study, there are three coders, which might violate the relaibility; in further studies, this problem can be handled through the involvement of many coders, who are expert in mass media in both local and international context, discourse and critical discourse analysis.

On the other hand, despite these limittaions, this research have some important implications for researchers, for governments, and for practitioners in mass media. The researchers, who are studying in the field of discourse and criticaly discourse analyses and specifically focusing on mass media, can follow contrastive analysis perspective fo deeper understanding the discursive acts performed in different mass media discourses. As for governments, the findings of this study suggest that, amid pandemics and epidemics, the mass media plays a crucial role in addressing large mass, and so they should invest in media agencies for public affairs campaigns. Lastly, practitioners in mass media discourse should focus on the force of texts in the genres they are designing in terms of persuasiveness; therefore, in social and global matters, they can construct the texts in collaboration with governments and researchers.

\section{Etik Beyan}

"Pragmatic Force of Covid-19 Ads as Health Protection Practices in Mass Media Discourse: A Contrastive Analysis Study." başlıklı çalışmanın yazım sürecinde bilimsel kurallara, etik ve alıntı kurallarına uyulmuş; toplanan veriler üzerinde herhangi bir tahrifat yapılmamış ve bu çalışma herhangi başka bir akademik yayın ortamına değerlendirme için gönderilmemiştir. Çalışma, metin çözümlemesi temelli olduğu için ve herhangi bir kurum/kuruluş/birim ve birey odaklı olmadığından dolayı etik kurul raporu alınmamışıtır.

\section{Teşekkür}

Bu çalışmanın bilimsel ve etik parametrelere göre yapılandırılması ve yürütülmesinde önem taşıyan nitel araştırma deseni ve bu desen odaklı süreçlere yönelik konulardaki değerli bilimsel desteği ve büyük katkıları için kıymetli hocam sayın Prof. Dr. Mustafa Sözbilir'e teşekkürü bir borç bilirim. 


\section{References}

Adegoke, L. (2001). Introduction to public relations: Principle, media, and methods. Ibadan: : Sulek-Temik Publishing Company.

Al-Dmour, H., Masa'deh, R., Salman, A., Abuhashesh, M., \& Al-Dmour, R. (2020). Influence of Social Media Platforms on Public Health Protection Against the COVID-19 Pandemic via the Mediating Effects of Public Health Awareness and Behavioral Changes: Integrated Model. J Med Internet Res, 22(8). Retrieved from http://www.jmir.org/2020/8/e19996/. doi:10.2196/19996

Al-Surimi, K., Khalifa, M., Bahkali, S., Ashraf, E., \& M., H. (2017). The potential of social media and internet-based data in preventing and fighting infectious diseases: from the internet to twitter. . Adv Exp Med Biol, 972, 131139. doi:10.1007/5584_2016_132

Austin, J. (1962). How to do things with words. Cambridge, MA: Harvard University Press.

Autores, V., Francis, B., Lea, D., Turnbull, J., Ashby, M., Phillips, P., . . Parkinson, D. (Eds.). (2010) Oxford Advanced Learner's Dictionary (8 ed.). Oxford, Uk: Oxford University Press

Bernhardt, D., Krasa, S., \& Polborn, M. (2008). Political polarization and the electoral effects of media bias. Journal of Public Economics, 92(5-6), 1092-1104.

Bertrand, M., Karlan, D., Mullainathan, S., Shafir, E., \& Zinman, J. (2010). What's advertising content worth? Evidence from a consumer credit marketing field experiment. The Quarterly Journal of Economics, 125(1), 263-306.

Catalan-Matamoros, D. (2011). The role of mass media communication in public health. In D. Smigorski (Ed.), Health Management-Different Approaches and Solutions (pp. 296-298): INTECH Open Access Publisher.

Chan, R. Y. K. (2000). The Effectiveness of Environmental Advertising: The Role of Claim Type \& the Source Country Green Image. International Journal of Advertising, 19, 349-375.

Chiang, C.-F., \& Knight, B. (2011). Media bias and influence: Evidence from newspaper endorsements. Review of Economic Studies, 78(3), 795-820.

Cho, H., Oehlkers, P., Mandelbaum, J., Edlund, K., \& Zurek, M. (2004). The Healthy Talk Family Planning Campaign of Massachusetts: A Communication-Centered Approach. Health Education, 104(5), 314-325.

Connor, U., \& Moreno, A. I. (2005). Tertium comparationis: A vital component in contrastive rhetoric research. In P. Bruthiaux, D. Atkinson, W. Eggington, W. Grabe, \& V. Ramanathan (Eds.), Directions in applied linguistics: Essays in honor of Robert B. Kaplan (pp. 153-164). Clevedon, UK: Multilingual Matters.

Cui, J., Sun, Y., \& Zhu, H. (2008). The impact of media on the control of infectious diseases. Journal of dynamics and differential equations, 20(1), 31-53. doi:10.1007/s10884-007-9075-0

DellaVigna, S., \& La Ferrara, E. (2016). Economic and social impact of mass media. In A. S. Anderson, J. Strömberg, \& i. D. Waldfogel (Eds.), Handbook of media economics (Vol. 2, pp. 723-768): Elsevier.

Fairclough, N. (1992). Discourse and social change. Cambridge: Polity Press.

Fairclough, N. (1995a). Critical Discourse Analysis. London: Longman.

Fairclough, N. (1995b). Media Discourse. London: Edward Arnold.

Gambaro, M., \& Puglisi, R. (2015). What do ads buy? Daily coverage of listed companies on the Italian press. European Journal of Political Economy, 39, 41-57.

Gerber, A. S., Karlan, D., \& Bergan, D. (2009). Does the media matter? A field experiment measuring the effect of newspapers on voting behaviour and political opinions. American Economic Journal: Applied Economics, 1(2), 35-52.

González-Padilla, D. A., \& Tortolero-Blanco, L. (2020). Social media influence in the COVID-19 Pandemic. International brazj urol, 46, 1-7. doi:10.1590/S1677-5538.IBJU.2020.S121

Hornik, R. (2002). Public health communication: Evidence for behavior change. UK: Routledge.

Jorgensen, M., \& Philips, L. J. (2002). Discourse analysis as theory and method. London, Thousand Oaks, New Delhi: SAGE Publications.

Jung, M., Lin, L., \& Viswanath, K. (2013). Associations between health communication behaviours, neighbourhood social capital, vaccine knowledge, and parents' H1N1 vaccination of their children. Vaccine, 31(42), 4860-4866. doi:10.1016/j.vaccine.2013.07.068 PMID: 23954379

Kearney, M. S., \& Levine, P. B. (2015). Media Influences on social outcomes: The impact of MTV's 16 and Pregnant on teen childbearing. American Economic Review, 105(12), 3597-3632.

Kim, Y.-J. (2006). The role of regulatory focus in message framing in anti-smoking advertisements for adolescents. Journal of Advertising, 35(1), 143-151.

Lau, J., Yang, X., Tsui, H., \& Kim, J. (2003). Monitoring community responses to the SARS epidemic in Hong Kong: from day 10 to day 62. J Epidemiol Community Health, 57, 864-870. doi:10.1136/jech.57. 11.864 PMID: 14600111

Lim, N. (2016). Cultural differences in emotion: differences in emotional arousal level between the East and the West. Integr Med Res, 5(2), doi: https://doi.org/10.1016/j.imr.2016.03.004

Lunn, P., Belton, C., Lavin, C., McGowan, F., Timmons, S., \& Robertson, D. (2020). Using Behavioral Science to help fight the Coronavirus. JBPA, 29(3). doi:10.30636/jbpa.31.147]

Majumder, M., Kluberg, S., Santillana, M., Mekaru, S., \& Brownstein, J. (2015). 2014 Ebola Outbreak: Media events track changes in observed reprodutive number. PLoS Curr. 2015, 7. doi:10.1371/currents.outbreaks. e6659013c1d7f11bdab6a20705d1e865 PMID: 25992303 
Maykut, P., \& Morehouse, R. (1994). Begining qualitative research: A philosophic and practical guide. London, UK: The Falmer Press.

Mejia, C. R., Ticona, D., Rodriguez-Alarcon, J. F., Campos-Urbina , A. M., Catay-Medina, J. B., Porta-Quinto, T., . . Tovani-Palone, M. R. (2020). The Media and their Informative role in the face of the Coronavirus disease 2019 (COVID-19): Validation of fear perception and magnitude of the Issue (MED-COVID-19). Electronic Journal of General Medicine, 17(6). doi:https://doi.org/10.29333/ejgm/7946

Moreno, A. I. (2008). The importance of comparable corpora in cross-cultural studies. In C. Ulla, N. Ed, \& R. William (Eds.), Contrastive Rhetoric: Reaching to Intercultural Rhetoric (pp. 25-41). Amsterdam: John Benjamins.

O'Connor, C., \& Joffe, H. (2020). Intercoder reliability in qualitative research: Debates and practical guidelines. International Journal of Qualitative Methods, 19, 1-19.

Pagoto, S., Waring, M., \& Xu, R. (2019). A Call for a Public Health Agenda for Social Media Research 19. J Med Internet Res, 21(12). doi:10.2196/16661

Roth, D. Z., \& Henry, B. (2011). Social distancing as a pandemic influenza prevention measure. Canada: National Collaborating Centre for Infectious Diseases.

Searle, J. (1969). Speech acts: An essay in the philosophy of language. Cambridge: Cambridge University Press.

Searle, J. (1979). Expression and meaning: Studies in the theory of speech acts Cambridge: Cambridge University Press.

Sharma, P., Gupta, S., Kushwaha, P., \& Shekhawat, K. (2020). Impact of mass media on quality of life during COVID-19 pandemic among Indian population. International Journal of Science and Healthcare Research, 5(3), 260267.

Smith, S., Smith, S., \& Ajayi, A. (2020). Content analysis of mass media reportage on coronavirus-19 (COVID-19) in Nigeria from six widely circulated Nigerian newspapers. 6(3), 088-099.

Tasnim, S., Hossain, M. M., \& Mazumder, H. (2020). Impact of rumors and misinformation on COVID-19 in social media. J Prev Med Public Health, 53, 171-174. doi:https:/ / doi.org/10.3961/jpmph.20.094

Wang, Q., Zhao, L., Huang, R., Yang, Y., \& Wu, J. (2015). Interactions of media and disease dynamics and its impact on emerging infection management. Discrete and Continuous Dynamical Systems-Series B, 20(1). doi: $10.3934 /$ dcdsb.2015.20.215

Zembylas, M., \& Vrasidas, C. (2007). Globalization, information and communication technologies, and the prospect of a 'global village': promises of inclusion or electronic colonization? Journal of Curriculum Studies, 37(1), 65-83. doi:10.1080/0022027032000190687

\section{TÜRKÇE GENIŞ ÖZET}

Küreselleşme, dijitalleşme ve sayısallaştırma arasındaki karşıklıklı ve süregelen etkileşimin bir sonucu olarak çeşitli kanalları ve yöntemleri barındıran ileitşim araç/türleri devamlı bir şekilde yeniden yapılandırılmakta ya da yeni iletişim araç/türleri ortaya çıkmaktadır (Zembylas ve Vrasidas, 2007); derin ve çok boyutlu yapısı ile medya söylemindeki bu araç/türler de; önceden yapılanmış kamu söylemini yönetebilen ya da yeniden şekillendiren ve hem görsel hem dilsel açıdan sofistike içeriği ile, olaylar ve konulara yönelik kamu davranışlarını etkileme ve düzenleme de önemli bir etkiye sahiptir (Bernhardt, Krasa ve Polborn, 2008; Bertrand, Karlan, Mullainathan, Shafir ve Zinman, 2010; Chiang ve Knight, 2011; DellaVigna ve La Ferrara, 2016; Gambaro ve Puglisi, 2015; Gerber, Karlan ve Bergan, 2009; Kearney ve Levine, 2015). Nitekim Covid-19 pandemisinin patlak vermesi ile birlikte ve hükümetlerin sağlık eylem planları ile eşzamanlı olarak, medya söyleminin küresel anlamda üstlenmiş olduğu rollerden biri de; Kovid19 pandemisinin gerçeklerine yönelik kamuyunu bilinçlendirecek ve böylece yeni normale adapte olmasını sağlayacak nitelikte düzenlenmiş mesajlar ile bireyleri bilgilendirme ve eğitmek olmuştur (González-Padilla ve Tortolero-Blanco, 2020; Smith, Smith ve Ajayi, 2020; Tasnim, Hossain ve Mazumder, 2020). Fakat, Kovid-19 pandemisi son bir yılda gelişen bir durum olduğu için bu konu üzerine medya söylemindeki metinlerin bilgi ve davranış yönetminde içeriklerinin nasıl yapılandırıldığı ve medya söyleminin bu husutaki rolünün bu metinler aracillğıyla irdelenmesine yönelik alanyazında oldukça az sayılda çalışma ve veri mevcuttur (González-Padilla ve Tortolero-Blanco, 2020; Smith, Smith ve Ajayi, 2020; Tasnim, Hossain, \& Mazumder, 2020). Dahası, kitle iletişim araçlarında Covid-19 pandemisi ile ilgili metinlerindeki iletişim edimleri, edimbilim bakışı ile ele alınmamış olduğu görülmektedir. Aslında, bu bakış ile irdelemek; söylemlerin hedef kitleyi etkilemede nasıl çalıştığını anlamada ve metinlerin dil edimlerinin ve özelliklerinin bu bağlamda ne olduğunun keşfedilmesinde oldukça önemlidir. Bu yüzden bu çalışma, dünyanın farklı yerlerindeki kitle iletişim tür/araçlarından biri olan reklamlardaki metinlerin dil edimlerini söz eylem teroisinden hareketle karşıtsal çözümleyerek (Austin, 1962; Searle, 1969, 1979) medya söyleminin Kovid19 pandemisindeki pragmatik gücünü keşfetmeyi amaçlamaktadır.

$\mathrm{Bu}$ amaçtan hareketle çalışma; olay, olgu, konu ve durumların anlamlandırılmasında dilin nasıl yapılandırıldığını odağına alan ve bağlamsal dil kullanımını irdeleyen söylem analizi paradigmasını rehber olarak almaktadır (Fairclough, 1995a; Jorgensen ve Philips, 2002). Medya söylemine yönelik söylem analizi 
çalışmaları ise genellikle eleştirel söylem analizi mantığında ilerlemekte olup bu mantık çerçevesinde de özel olarak dil örüntülerinde vurgulanan sosyal değişim olgusu ve türü ortaya çıkarılmaya çalışılmaktadır (Fairclough, 1992, 1995a, 1995b). Dolayısıyla, bu çalışma; söylem ve eleştirel söylem analizi paradigması çerçevesinde sunulan bakış açılarını Covid-19 reklamlarındaki dil edimlerini detaylı bir şekilde incelemek üzere konuya yaklaşım felsefesi olarak almıştır. Bu noktada, çalışma metin ve bağlam odaklı bir çalışma olduğu için çalışmanın deseni nitel yönelimlidir, çünkü nitel bakış açısında gerçek çok yönlü, ortam, durum ve değerlere göre çeşitlilik gösterir (Maykut ve Morehouse, 1994). Bu yüzden, bu çalışmanın temel amacı; farklı bağlamlardaki medya söyleminde yer alan Covid-19 reklamlarının pragmatik gücünü, bir diğer ifade ile edimsel eylemini, sağlık koruma eylemleri bağlamında, karşıtsal olarak çözümlemektir. Bu amaç doğrultusunda, çalışmanın veri kaynağını Asya, Avrupa ve Amerika'daki medya bağlamlarında yayınlanmış 450 adet reklam oluşturmaktadır. Bu reklamlar, derlem analizi çalışmalarında ortaya konulmuş olan belirli ölçütlerden hareketle seçilmiş olup bu noktada karşıtsal çözümlemede öncü olan uzmanların alanyazında sunmuş oldukları aşamalar takip edilerek çalş̧manın derlemi oluşturulmuştur (Moreno, 2008). Analiz sürecinde, Austin (1962) ve Searle $(1969,1979)$ tarafından geliştirilmiş olan Söz Eylem Teorisinin sunmuş olduğu şablondaki edimsel eylemler kategorileri kullanılmışır; bu aşamada, araştırmacı ile beraber reklam alanında uzman olan iki akademisyen bağımsız bir şekilde metinleri kodlamış, ardından SPSS’e aktarılan kodlamalar kodlayıcı güvenirliliği ölçümü için yüzdelik karşılaştırmaya tabi tutulmuştur. Kodlayıcılar arası güvenilirlik yüzdesi, \% 73.51 olarak hesaplanmıştır.

Kodlama sonucu bulgular, hiyerarşik olarak Covid-19 reklamlarında en sık uygulanan edimsel eylemler sırasıyla yönlendirici ve iddiacı eylemler olduğunu göstermektedir. Oransal olarak bakıldığında, \% Covid-19 reklamlarının \%28'inde yönlendiri edimsel eylemler, \%27'sinde ise iddiacı edimsel eylemler olduğu gözlemlenmiştir. Derlemde en az yüzdeliğe sahip olan edimsel eylem ise dişavurumcu eylemlerdir (\%6). Buna karşın, derlemin yaklaşık \%20'sinde yüklenme edimsel eylemi, \%19'unda da bildirme eylemleri olduğu tespit edilmiştir. Bu bulgular ışığında, Covid-19 reklamlarının bireysel davranışlarda bir değişimi tetikleyici yönde kamu söylemini yönetme amacıyla yapılandırılmış olduğu sonucuna varılabilir. İşlevsel olarak reklamların bu şekilde tasarlanmasının arkasında yatan temel neden ise, kamuyu, açık bir şekilde sorun yönetimini vurgulayarak ve bir dizi öneriyi doğrudan ya da dolaylı bir şekilde listeleyerek pandeminin gerçeklerinden hareketle günlük faaliyetlerini yeniden gözden geçirme ve düzenlemeye davet etme rolünü üstlenmektir. Bu noktada, şunu da vurgulamak gerekir ki kamu söyleminin yönetiminde reklamalr Covid19 pandemisi ile birlikte değişen gerçekliği vurgulamak üzere tasarlanmış gibi görünmektedir. Bunların yanı sıra, Covid-19 reklamlarındaki metinler, sağlık koruma uygulamaları kapsamında benimseyecekleri eylem ve hareketler ve alacakları sorumluluklara yönelik kamunun bağlı kalacağı geçici bir tür anlaşmaya da işaret etmektedir. 